\title{
Monitoring the Levels of Essential and Trace Metals in Groundwater along Fuoni Area in Zanzibar
}

\author{
Abdul Ali Juma Mohamed", Sara A. Khamis, Miza Ali Kombo \\ Department of Natural Sciences, State University of Zanzibar (SUZA), Zanzibar, Tanzania \\ Email address: \\ jumabdull@yahoo.com (A. A. J. Mohamed) \\ ${ }^{*}$ Corresponding author
}

\section{To cite this article:}

Abdul Ali Juma Mohamed, Sara A. Khamis, Miza Ali Kombo. Monitoring the Levels of Essential and Trace Metals in Groundwater along Fuoni Area in Zanzibar. Journal of Water Resources and Ocean Science. Vol. 5, No. 3, 2016, pp. 37-46. doi: 10.11648/j.wros.20160503.12

Received: May 24, 2016; Accepted: June 3, 2016; Published: June 21, 2016

\begin{abstract}
Physico-chemical parameters of groundwater resources were studied in Fuoni area allocated at West District of Zanzibar Island. In June 2014, water samples were collected from ten groundwater sources for physico-chemical analysis. The chemical parameters include twenty metals (Al, As, $\mathrm{Be}, \mathrm{Ca}, \mathrm{Cd}, \mathrm{Co}, \mathrm{Cr}$ (III), Cu, Fe, $\mathrm{Li}, \mathrm{Mg}, \mathrm{Mn}, \mathrm{Na}, \mathrm{Ni}, \mathrm{Pb}, \mathrm{Se}, \mathrm{Sr}, \mathrm{Tl}, \mathrm{V}$ and $\mathrm{Zn}$ ). Inductively Coupled Plasma Emission Spectroscopy (ICP-OES) determined the dissolved metal concentrations. The levels of total dissolved solid (TDS), turbidity, electrical conductivity (EC), and $\mathrm{pH}$ were also determined using Horiba multiparameter water quality meter. There was no detection for the levels of $\mathrm{Al}, \mathrm{Be}, \mathrm{Cd}, \mathrm{Co}$, and $\mathrm{Mn}$ in all water samples. Notably, the physico-chemical parameters suggest that the groundwaters in this area are generally good for domestic use per World Health Organization (WHO) standards. Nevertheless, $40 \%$ of the analyzed water samples had elevated levels of calcium as compared to WHO guideline for calcium. Turbidity levels in majority of water samples were beyond the recommended guideline value. Both $\mathrm{Sr} / \mathrm{Ni}$ ratio and $\mathrm{Li} / \mathrm{Ni}$ ratio were greater than 1 . Furthermore, four heavy metals namely, $\mathrm{Cu}, \mathrm{Fe}, \mathrm{Zn}$, and $\mathrm{Pb}$ were used in a multivariate hazard analysis. The hazard analysis aimed at evaluating a potential human health risks associated with water consumption from the study area. The analysis included, heavy metal evaluation index (HEI), heavy metal pollution index (HPI), degree of metal contamination $\left(\mathrm{C}_{\mathrm{d}}\right)$, and hazard quotient which yields hazard index $(\mathrm{HI})$. Generally, there was no apparent risk to water consumers from being exposed to studied metals. Nevertheless, knowledge and awareness of the quality of drinking water is crucial, hence, the presence of trace and heavy metals in water sources necessitates the need of regular monitory of water sources. Therefore, a good and sustainable management of drinking water quality is an inevitable factor in preventing and controlling of the waterborne diseases.
\end{abstract}

Keywords: Hazard Index, Sr/Ni Ratio, Thallium, Fuoni, Zanzibar

\section{Introduction}

Fuoni is a newly and ever growing area in west District of Zanzibar Island. Groundwater from wide diameter hand dug wells and bore hole wells is the principal water resources in this area. Groundwater, such as borehole water and well water, and surface water, such as lakes, rivers, and streams are the two principal natural sources of fresh water [15]. Over the last decade, groundwater resource has become the potential source of domestic water supply in worldwide [10].

Intriguingly, various water quality analysis, and public health surveys have shown that groundwater resources are vulnerable to contaminants. These contaminants may include species such as waterborne pathogens, toxic elements, and other chemicals or biological species [3]. Over the last few years, surface water and groundwater resources are among the most important environmental issues due to heavy metals contamination and human industrial activities [9, 13, 21]. In recent study, groundwater quality, water type, and sources of contaminants have been explored using Piper, Stiff plots and multivariate statistical techniques [2].

Groundwater quality is important in many sectors, such as agriculture, aquaculture, and industries [27]. However, the lack of sufficient clean and safe water along with inadequate 
sanitary infrastructures leave millions exposed to high-level of health risks, which can intensify the harshness on their daily life [1]. The United Nation had estimated that 1.7 billion people do not have adequate supply of portable drinking water [7]. Cholera, diarrhea, and other waterborne diseases have been estimated to cause 2.2 million deaths every year [28]

Some of the heavy metals are essential for growth, development, and health, while others are categorized as toxic species on living organisms [25]. Table-1 summarizes the health impacts and medical implication of some physicochemical parameters.

Table 1. Water-Quality Criteria, Standards and Health Impacts and Medical Implication of Selected Parameters.

\begin{tabular}{|c|c|c|}
\hline Parameter & Standard SMCL & Health Impacts and or Medical Implication \\
\hline $\mathrm{Fe}$ & $300 \mu \mathrm{g} / \mathrm{L}$ & It can promote growth of certain kinds of bacteria that clog pipes and well openings \\
\hline $\mathrm{Pb}$ & $15 \mu \mathrm{g} / \mathrm{L}$ & $\begin{array}{l}\text { A cumulative poison and toxic in small concentrations. It can cause lethargy, loss of appetite, constipation, anemia, } \\
\text { abdominal pain, and gradual paralysis in the muscles }\end{array}$ \\
\hline $\mathrm{Li}$ & - & $\begin{array}{l}\text { Beneficial in concentration range of } 250-1,250 \mu \mathrm{g} / \mathrm{L} \text {. It may help in strengthen the cell wall and in improving } \\
\text { resistance to genetic damage and to disease }\end{array}$ \\
\hline Mn & $50 \mu \mathrm{g} / \mathrm{L}$ & $\begin{array}{l}\text { It causes gray or black stain on enamel, porcelain, and fabrics. It can promote growth of certain kinds of bacteria that } \\
\text { clog pipes and wells }\end{array}$ \\
\hline $\mathrm{Hg}$ & $2 \mu \mathrm{g} / \mathrm{L}$ & $\begin{array}{l}\text { It is not essential or beneficial role in human or animal nutrition. Some mercury compounds, such as mercuric } \\
\text { chloride and alkyl mercury, are very toxic. Potential health effects of exposure to some mercury compounds in water } \\
\text { include severe kidney and nervous system disorders }\end{array}$ \\
\hline $\mathrm{Ni}$ & $20 \mu \mathrm{g} / \mathrm{L}$ & It is very toxic to some plants and animals. Toxicity for humans is believed to be very minimal \\
\hline $\mathrm{Se}$ & $50 \mu \mathrm{g} / \mathrm{L}$ & $\begin{array}{l}\text { It is essential to human and animal nutrition in minute concentrations. However, even a moderate excess may be } \\
\text { harmful or potentially toxic if ingested for a long time. Potential human health effects of exposure to elevated } \\
\text { selenium concentrations include liver damage }\end{array}$ \\
\hline $\mathrm{Sr}$ & - & $\begin{array}{l}\text { Its importance in human and animal nutrition is not known, but believed to be essential. Its toxicity is believed to be } \\
\text { very minimal }\end{array}$ \\
\hline $\mathrm{Zn}$ & $5000 \mu \mathrm{g} / \mathrm{L}$ & $\begin{array}{l}\text { It is essential and beneficial in metabolism; its deficiency in young children or animals will retard growth and may } \\
\text { decrease general body resistance to disease. Appears to have no ill effects even in fairly large concentrations }(20,000 \text { - } \\
40,000 \mathrm{mg} / \mathrm{L}) \text {, but can impart a metallic taste or milky appearance to water }\end{array}$ \\
\hline Turbidity & $1 \& 5 \mathrm{NTU}$ & $\begin{array}{l}\text { Associations between drinking water turbidity and GI illness have been found in two settings, in people of various } \\
\text { ages, diarrheal illness and lab-confirmed cryptosporidiosis }\end{array}$ \\
\hline
\end{tabular}

SMCL $=$ Secondary Maximum Contaminant Level

Heavy metal contamination has become a significant problem in several community and agricultural areas over the years due to the application of commercial agrochemicals on agricultural production [23]. However, heavy metals originating from anthropogenic sources have been found in all components of the environment [4, 11, 12]. In recent years, more attention has been devoted to pollutants in the environment due to increase in anthropogenic contribution by heavy metals $[8,14]$. Heavy metals can eventually dispersed and accumulated in the soil as well as surface and groundwater and may therefore affect adverse human health effect to living organisms [6, 22, 24]. The International Agency for Research on Cancer (IARC) has categorized Cd and its compounds as group 1 human carcinogen, and classified inorganic $\mathrm{Pb}$ compounds as probably human carcinogen (Group 2A) and organic $\mathrm{Pb}$ as possible human carcinogen (group 2B) [5]. Therefore, human health risk assessment plays significant role inthe process of estimating the nature and probability of adverse health effects in humans associated with the exposure to hazards in contaminated environments [26].
Groundwater signifies an important source of drinking water, however, its quality might be threatened by a factors such as geological variation (such as soil type), water and soil chemistry. There are also other anthropogenicalenhanced factors, which lead to groundwater contaminations. For instances all activities conducted around the drinking water sources, onsite leaky septic tanks, and pit latrines. All these factors influence the transportation, distribution, and fate of the chemicals, and other contaminants in the groundwater aquifers [20].

As water quality is an environmental determinant of health, the knowledge, and awareness of the quality of drinking water remains crucial. The management and sustainability of good drinking water quality is an important factor in prevention and control of the waterborne diseases. Thus, the present study highlights the levels of some physicochemical parameters of groundwater resources along Fuoni area in Zanzibar Island. The levels of $\mathrm{pH}$, turbidity, electrical conductivity (EC), total dissolved solid (TDS) and hazard indices were also investigated. 


\section{Materials and Methods}

\subsection{Sampling}

In June 2014, ten water samples were collected from different sites along Fuoni area. The sources of the collected water samples were; open hand dug wells and closed hand dug wells. Samples were collected in pre-cleaned polyethylene bottles. The handling, storage and preparation of the samples were done in accordance with the standard EPA method 2007

\subsection{Analytical Procedure}

Turbidity, pH, EC and TDS were measured using Horiba multiparmaeter water quality meter, while an Inductively Coupled Plasma-Optical Emission Spectrometry, ICP-OES (Thermo Scientific iCAP 6000) was used to determine the leveles of metals. Prior to water sampling, all the glass bottles were cleaned, and rinsed thoroughly with the sampled water. All reagents used were of analytical grade. Samples for the analysis of chemical parameters were filtered using disposable Merck $0.45 \mu \mathrm{m}$ filter Millipore. Thus, the analysis yielded the concentrations of metals, which correspond to the dissolved concentrations. The ground water samples were stored at $1-4^{\circ} \mathrm{C}$ temperature prior to chemical analysis in the laboratory. Metal analyzed include $\mathrm{Al}, \mathrm{As}, \mathrm{Be}, \mathrm{Ca}, \mathrm{Cd}, \mathrm{Co}, \mathrm{Cr}$ (III), Cu, Fe, Li, Mg, $\mathrm{Mn}, \mathrm{Na}, \mathrm{Ni}, \mathrm{Pb}, \mathrm{Se}, \mathrm{Sr}, \mathrm{Tl}, \mathrm{V}$ and $\mathrm{Zn}$.

\section{Result}

SPSS version 16 was used for the data analysis. The summary of the descriptive statistics of the analyzed parameters in water samples is presented in Table-2.

Table 2. Summary of the Descriptive Statistics of the analyzed parameters in water samples.

\begin{tabular}{|c|c|c|c|c|c|c|}
\hline Parameter & Range & Minimum conc. $(\mathrm{mg} / \mathrm{L})$ & Maximum conc. (mg/L) & Mean & Std. Deviation & WHO/ US EPA guideline \\
\hline As & 0.0005 & $\mathrm{BDL}$ & 0.0005 & 0.00005 & 0.000158 & $0.01^{\mathrm{a}}$ \\
\hline $\mathrm{Ca}$ & 132.913 & 5.787 & 138.7 & 71.8317 & 51.96642 & $100^{\mathrm{a}}$ \\
\hline $\mathrm{Cr}$ (III) & 0.0228 & BDL & 0.0228 & 0.01422 & 0.00798 & - \\
\hline $\mathrm{Cu}$ & 0.0261 & $\mathrm{BDL}$ & 0.0261 & 0.005 & 0.00766 & $2^{\mathrm{a}}$ \\
\hline $\mathrm{Fe}$ & 0.0015 & BDL & 0.0015 & 0.00015 & 0.000474 & $0.3^{\mathrm{a}}$ \\
\hline $\mathrm{Li}$ & 0.0818 & 0.0123 & 0.0941 & 0.04261 & 0.029475 & - \\
\hline $\mathrm{Mg}$ & 5.6856 & 0.2914 & 5.977 & 2.86706 & 1.875713 & $50^{\mathrm{a}}$ \\
\hline $\mathrm{Na}$ & 68.35 & 4 & 72.35 & 24.3087 & 24.62121 & $175^{\mathrm{a}}$ \\
\hline $\mathrm{Ni}$ & 0.005 & $\mathrm{BDL}$ & 0.005 & 0.00282 & 0.001623 & $0.02^{\mathrm{b}}$ \\
\hline $\mathrm{Pb}$ & 0.0014 & BDL & 0.0014 & 0.00024 & 0.000515 & $0.015^{\mathrm{a}}$ \\
\hline $\mathrm{Sr}$ & 0.0254 & 0.0064 & 0.0318 & 0.01669 & 0.007629 & - \\
\hline $\mathrm{Tl}$ & 0.0568 & 0.0159 & 0.0727 & 0.04106 & 0.016209 & $0.002^{\mathrm{a}}$ \\
\hline V & 0.059 & BDL & 0.059 & 0.03614 & 0.020756 & - \\
\hline $\mathrm{Zn}$ & 0.1743 & BDL & 0.1743 & 0.02848 & 0.05461 & $3^{\mathrm{a}}$ \\
\hline $\mathrm{pH}$ & 1.95 & 6.53 & 8.48 & 7.389 & 0.682845 & $6.5-8.5^{\mathrm{a}}$ \\
\hline $\mathrm{EC}$ & 347 & 121 & 468 & 310.9 & 109.1985 & $1000^{\mathrm{a}}$ \\
\hline Turbidity & 7.67 & 0 & 7.67 & 1.812 & 2.785789 & $<1^{\mathrm{c}} \&<5^{\mathrm{d}}$ \\
\hline TDS & 223 & 81 & 304 & 209 & 76.59417 & $500^{\mathrm{a}}$ \\
\hline
\end{tabular}

${ }^{\mathrm{a}}$ As per WHO guideline, ${ }^{\mathrm{b}}$ As per US EPA; ${ }^{\mathrm{c}}$ If water was disinfected by chlorine, ${ }^{\mathrm{d}}$ If water was not disinfected

$\mathrm{EC}$ in $\mu \mathrm{S} / \mathrm{cm}$, Turbidity in NTU, all other parameters in $\mathrm{mg} / \mathrm{L}$ except $\mathrm{pH}$ no unit

Notably, in the study area, the levels of $\mathrm{Mn}, \mathrm{Co}, \mathrm{Cd}, \mathrm{Be}$, $\mathrm{Ni}, \mathrm{Se}$, and $\mathrm{Al}$ were detected of all in water samples.

\subsection{Concentration of $Z n$ in Water Samples}

The range of zinc in water samples was BDL -0.1743 $\mathrm{mg} / \mathrm{L}$ (Table-2; Figure-1). In all the aquifers in the study area, none of the samples analyzed for zinc exceeded the WHO standard (Figure A1). With this regard, consumption of drinking water from the study area can be a potential source for zinc mineral beneficial in human metabolism. Its deficiency can cause deterioration in the growth of young children or animals, which in turn may increase their general resistances to disease.

However, because the soil is a potential reservoir of all the metals in Earth crust, thus the occurrence and the detected concentrations of the trace metals in water sources is not an anomalous event [17]. 


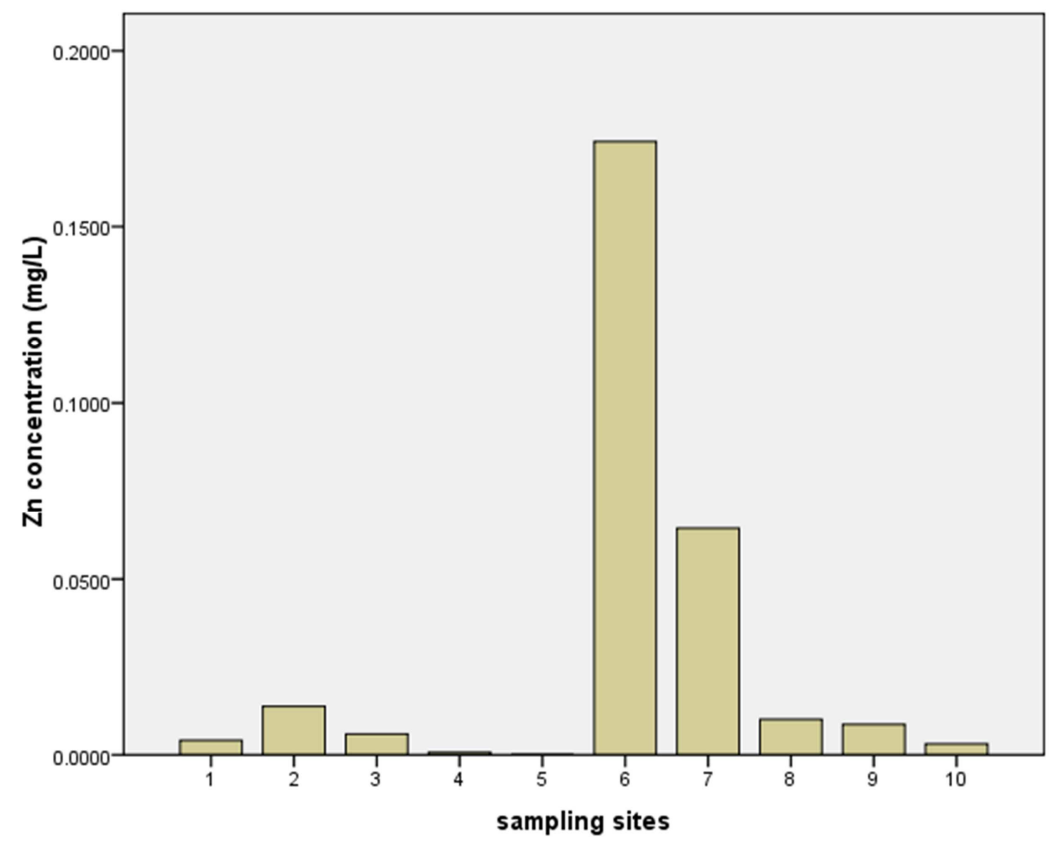

Figure 1. Concentration of $Z n$ in water samples.

\subsection{Concentration of Mg in Water Samples}

The range of magnesium in water samples was $0.2914-5.77 \mathrm{mg} / \mathrm{L}$ (Table-2; Figure-2). None of the samples analyzed for magnesium exceeded the WHO standard. Thus, consumption of drinking water from the study area can serve as a potential source of magnesium mineral beneficial for human consumptions.

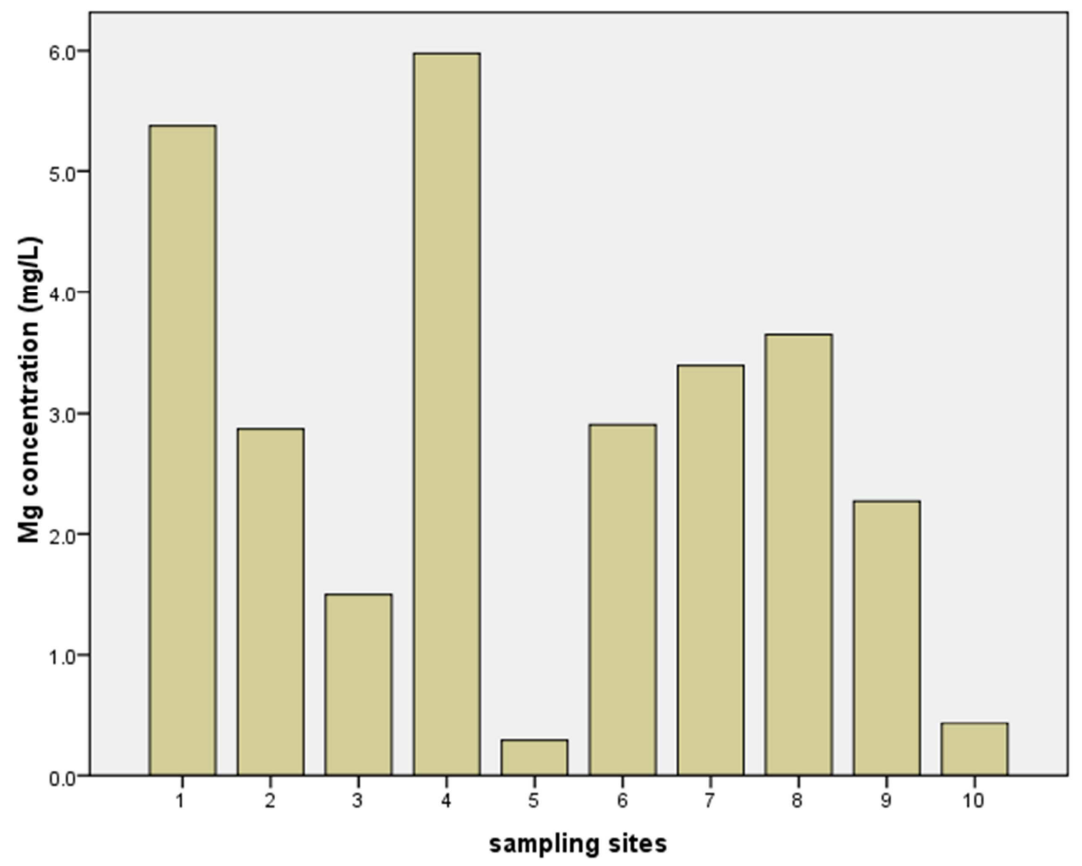

Figure 2. Concentration of $\mathrm{Mg}$ in water samples.

\subsection{Concentration of $\mathrm{Cu}$ and $\mathrm{Ni}$ in Water Samples}

The ranges of copper and nickel were BDL $-0.0261 \mathrm{mg} / \mathrm{L}$, and BDL $-0.005 \mathrm{mg} / \mathrm{L}$, respectively (Table-2; Figure-3. The values of these parameters in each sampling station were within the WHO and USEPA recommended guideline values.
Remarkably, the ratio of lithium to nickel in all water samples has been found to be greater than a unit (Figure A1). This observation suggests that in the study area, the relative abundance of lithium is higher as compared to nickel. Similar trend of lithium to nickel ratio was revealed in recent study at North region of Zanzibar Island [17]. 


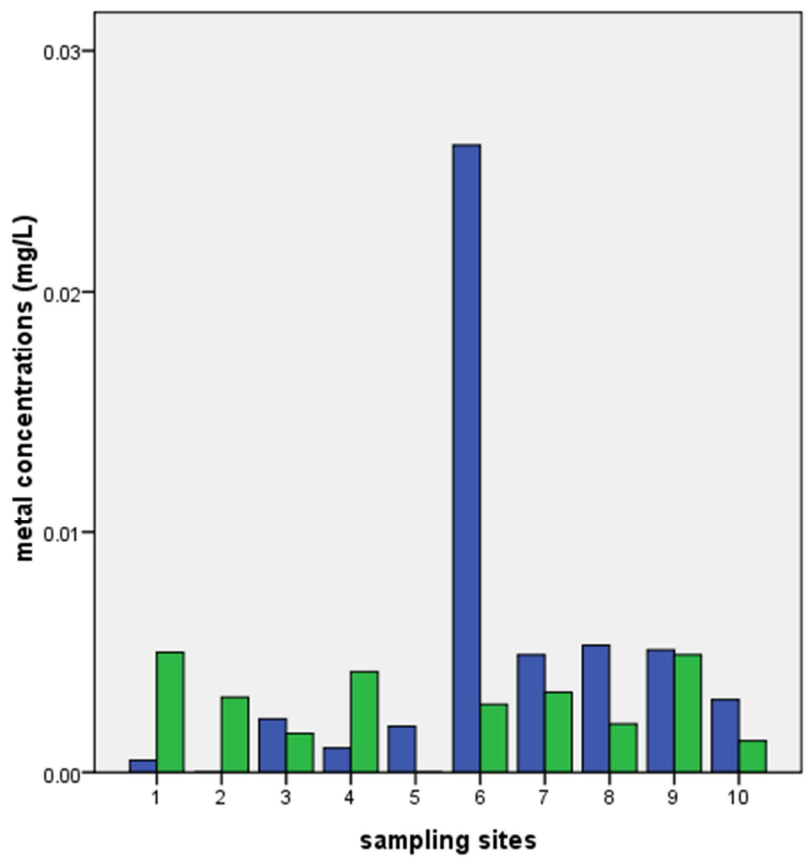

$\square \mathrm{Cu}(\mathrm{mgh})$

Figure 3. Concentrations of $\mathrm{Cu}$ and $\mathrm{Ni}$ in water samples.

\subsection{Concentrations of Sr, Li, $\mathrm{Tl}$, As, and Cr III in Water Samples}

The ranges of strontium, lithium, thallium, and chromium (III) in the analyzed samples were; Sr: $0.0064-0.0318 \mathrm{mg} / \mathrm{L}$;

Li: $0.0213-0.0941 \mathrm{mg} / \mathrm{L}$; Tl: $0.0159-0.0727 \mathrm{mg} / \mathrm{L}$;

As: BDL - $0.0005 \mathrm{mg} / \mathrm{L}$, and $\mathrm{Cr}$ (III): $\mathrm{BDL}-0.0228 \mathrm{mg} / \mathrm{L}$ (Table-2; Figure-4). The values of thallium for all water samples $(100 \%)$ in the study area exceeded the WHO recommended guideline, anthropogenic sources could be influential factor for the presence of thallium in water samples. Moreover, recent study also reveals the occurrence of thallium in Zanzibar water resources [18]. The presence of contaminants in groundwater could be a consequence of anthropogenic activities, such as improper disposal of used electronic devices (e-wastes), tires, and other waste materials. Besides, the application of fertilizers, pesticides, and metalcontaining paints can lead to considerable groundwater pollution [17]. Currently, there is no guidelines are available yet for chromium (III), lithium, and strontium.

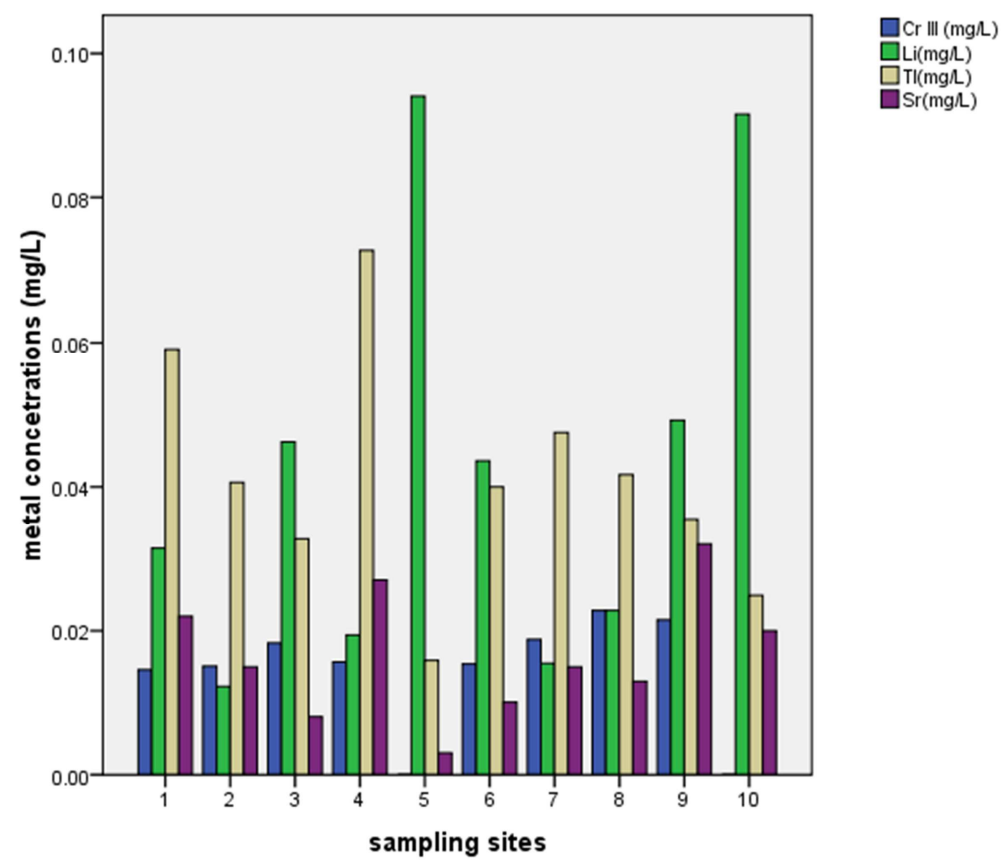

Figure 4. Concentrations of Sr, Li, Tl and Cr III in water samples. 


\subsection{Concentrations of Na and Ca in Water Samples}

The ranges of sodium and calcium in the analyzed samples were $4-72.35 \mathrm{mg} / \mathrm{L}$ and $5.787-138.7$ respectively (Table-2; Figure-5). None of the analyzed sample had sodium and calcium concentration beyond the WHO guideline. The consumption of water from the study can serve considerable amount of these minerals required human daily metabolism.

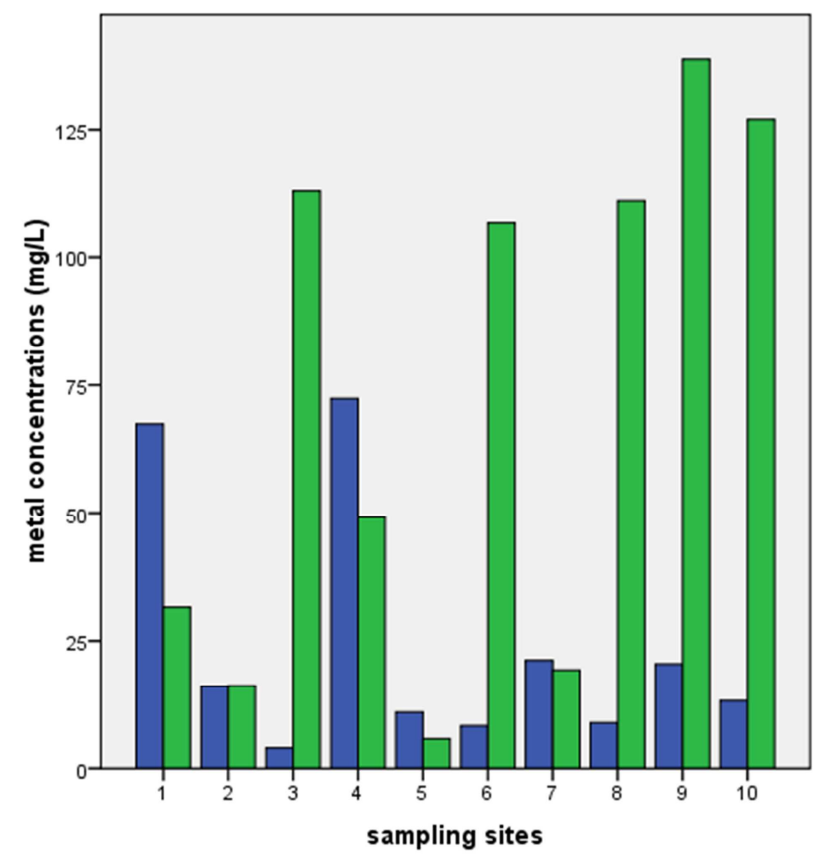

$\square \mathrm{Na}(\mathrm{mg} / \mathrm{L})$

Ga(mgL)

Figure 5. Concentrations of $\mathrm{Na}$ and $\mathrm{Ca}$ in water samples.

\subsection{TDS, EC, Turbidity, and pH in Water Samples}

The ranges of TDS, EC, turbidity, and $\mathrm{pH}$ were; $81-304 \mathrm{mg} / \mathrm{L}, 121-468 \mu \mathrm{S} / \mathrm{cm}, 0-7.67 \mathrm{NTU}$, and $6.53-8.48$ respectively. Basically, the values of these parameters were within the WHO recommended guideline value (Table-2). The EC correlates positively with TDS $\left(\mathrm{r}^{2}=0.884\right)$, and these two parameters exhibit regular patterns within the sampling sites (Figure-6). Contrarily to the pattern shown between TDS and EC, the $\mathrm{pH}$ and turbidity exhibit an irregular pattern, which signifies poor correlation between these two parameters (Figure-7).
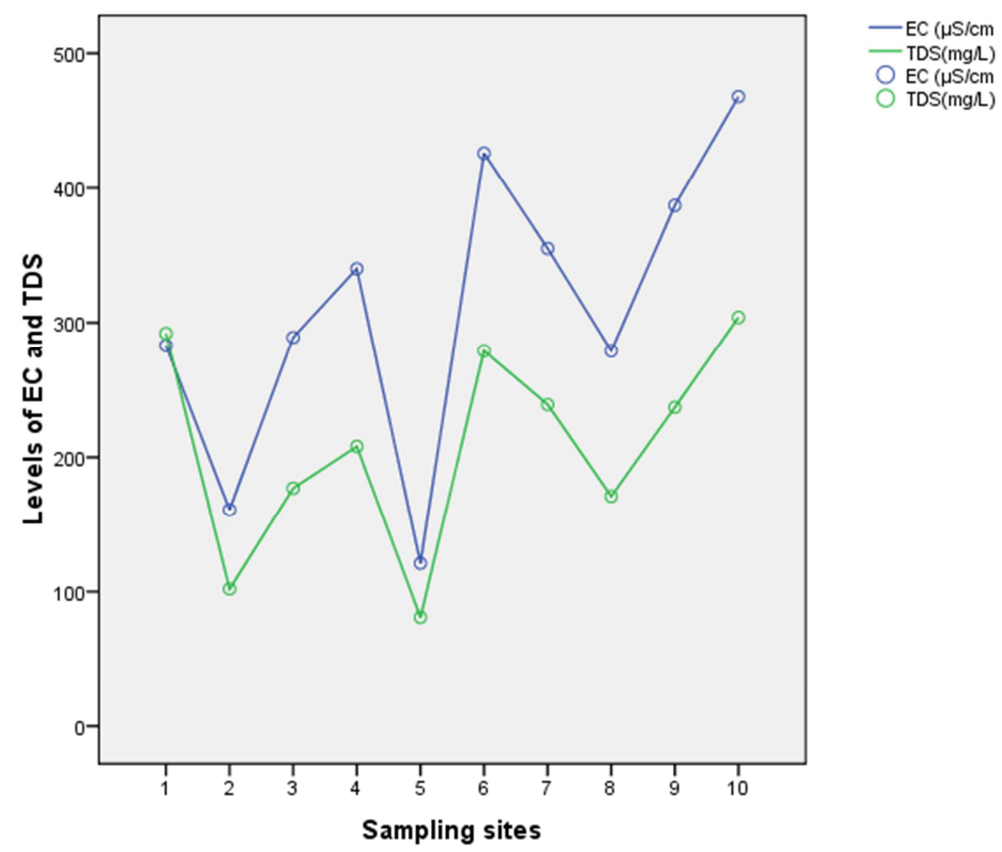

Figure 6. Levels of EC and TDS in water sources. 

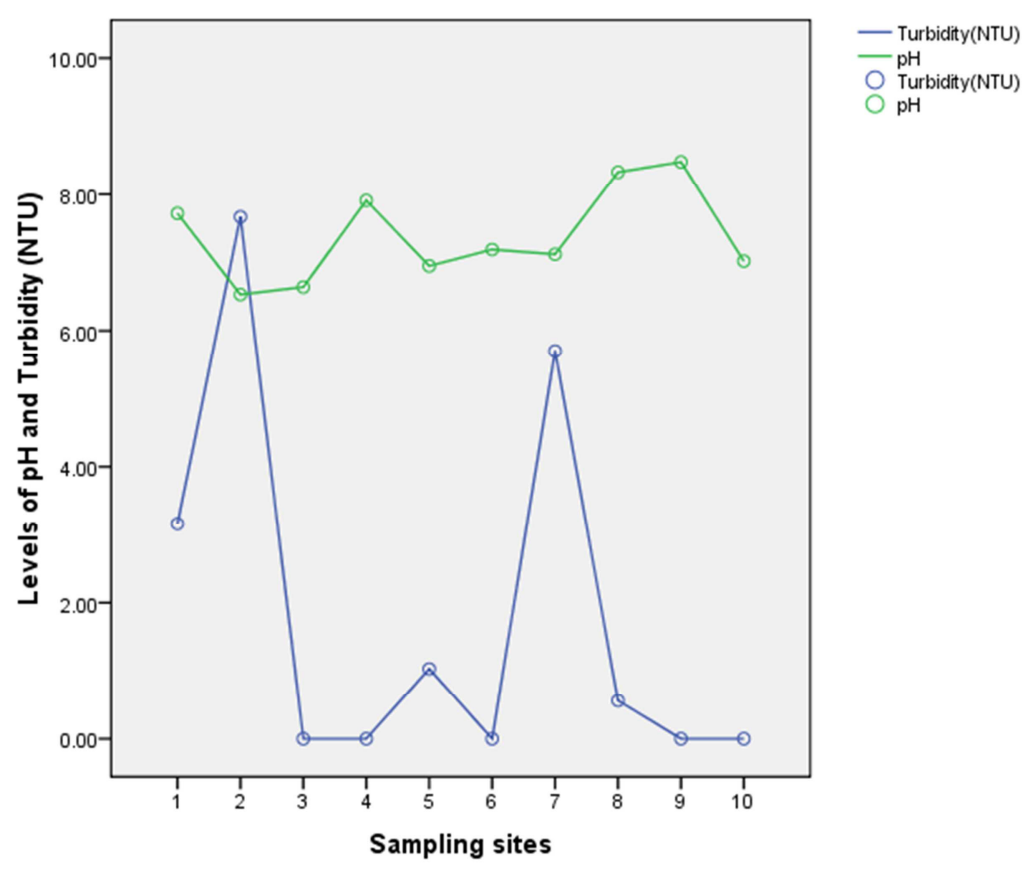

Figure 7. Levels of pH and turbidity in water sources.

\subsection{Hazard Indices (HEI and HI)}

The ranges of these two parameters were; $0.00114-0.0967313$, and $0.001193-0.058102$, respectively. At varying degree, all water samples have shown some levels of HEI and HI (Figure-8, Figure A2).
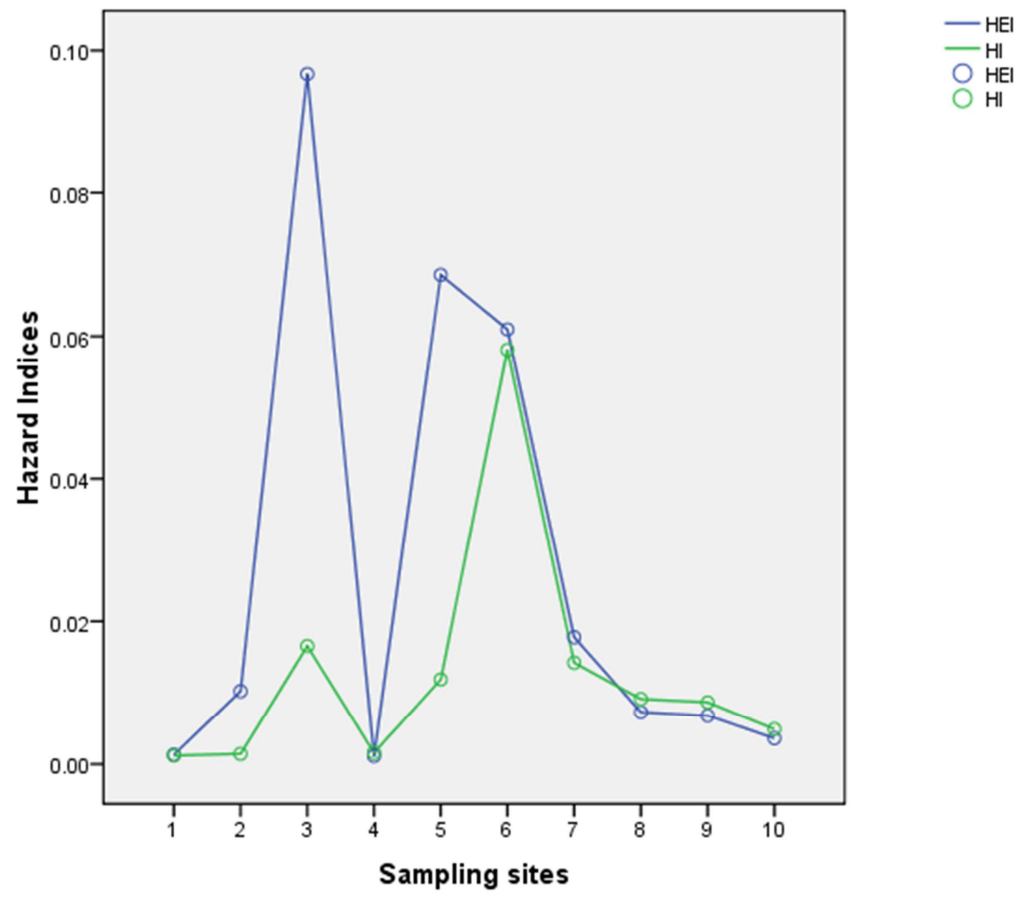

Figure 8. Metal Hazard indices (HEI and HI) in water sources.

\subsection{HPI, HEI, and $C_{d}$ Levels in Water Samples}

Four metals namely; $\mathrm{Cu}, \mathrm{Fe}, \mathrm{Zn}$, and $\mathrm{Pb}$ were used to depict the level HPI, HEI and $C_{d}$. The values of HPI and $C_{d}$ for each water samples have been found to be less than zero. Negative values for HPI and $C_{d}$ were also reported in recent study conducted in groundwater sources at Urban environment in Zanzibar Island [19]. The values of HEI were in the range of $0.00114-0.096713$ (Figure A2). This observation can be taken as indication of low level of metallic pollution in the study area. Remarkably, the correlation between $\mathrm{C}_{\mathrm{d}}$ and HEI was found to be very strong with Pearson coefficient of 1 (Figure-9). 


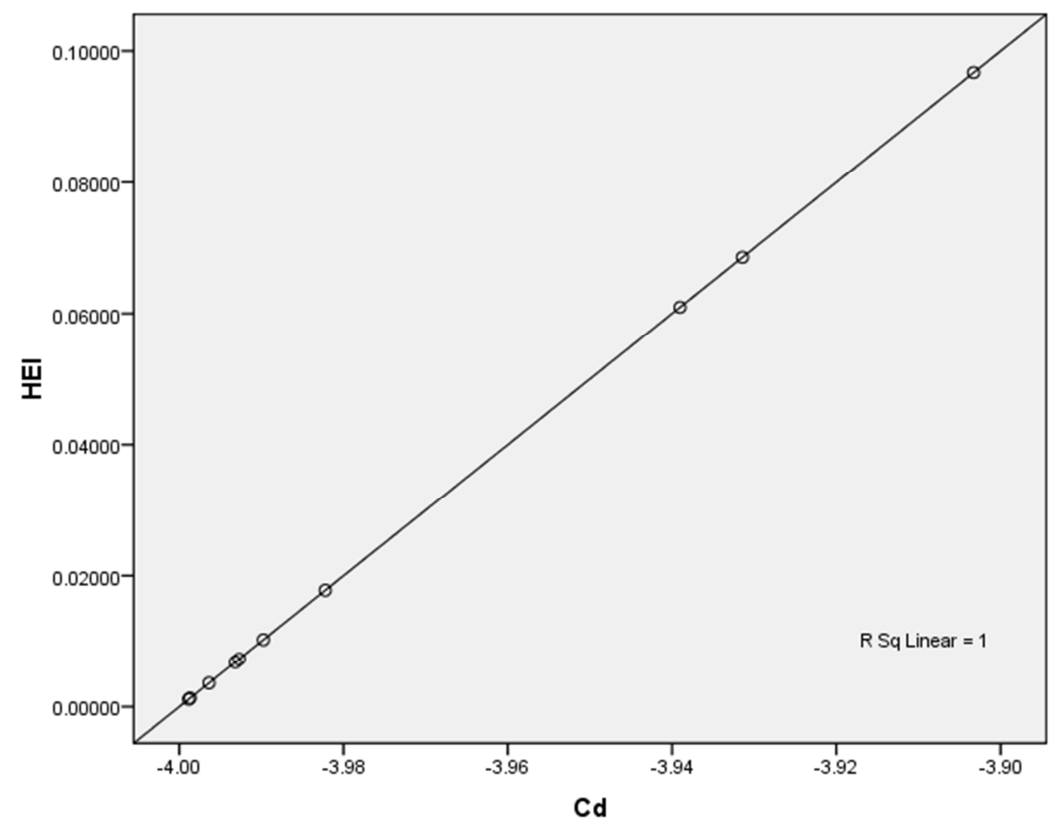

Figure 9. HEI- Cd Correlation in water sources.

\subsection{Chronic Daily Intake of $\mathrm{Cu}, \mathrm{Fe}, \mathrm{Zn}$, and $\mathrm{Pb}$}

The chronic daily intake was measured separately using copper, iron, zinc, and lead. The trend for the daily intake of these metals was: ADD:Zn > ADD: $\mathrm{Cu}>$ ADD: $\mathrm{Pb}>$ ADD: Fe (Figure A2). Remarkably, strong correlation $\left(\mathrm{r}^{2}=0.896\right.$ ) was shown between the ADD of copper and zinc (Figure-10).

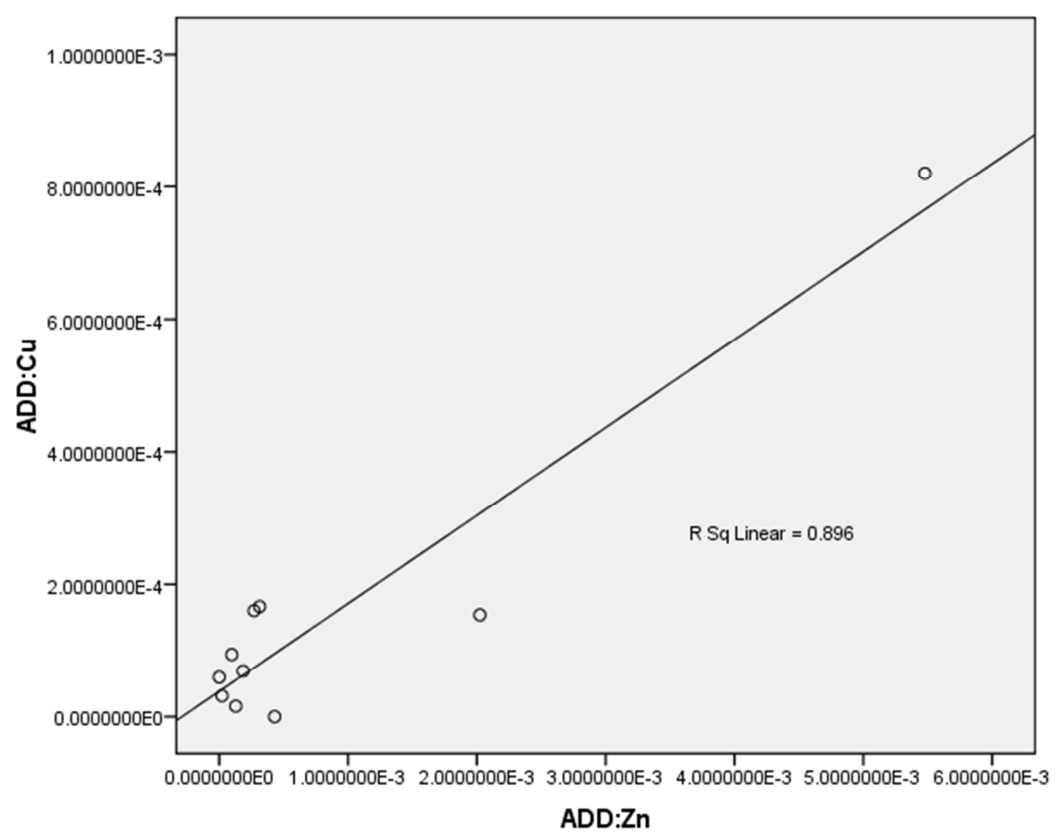

Figure 10. $A D D$ : $C u$-Zn Correlation in water sources.

\subsection{Correlation Between the Analyzed Parameters in the Water Sources}

While strong positive correlations existed for some of the analyzed parameters, some negative correlations were also observed. As an example, thallium has shown strong positive correlations with magnesium and sodium. Thallium relationship with magnesium and sodium were found to have
Pearson correlation values of 0.974 and 0.833 respectively (Table-3). The correlation between same parameters is not necessarily constant, and it can differ remarkably from one study area to another. In the analytical chemistry perspective, the correlation matrix is a fundamental and pervasive concept, and it does not necessarily mean the presence of causality among the analyzed parameters [19]. 
Table 3. Correlation matrix for the selected physico-chemical parameters.

\begin{tabular}{|c|c|c|c|c|c|c|c|c|c|c|}
\hline Parameters & $\mathrm{Ca}$ & $\mathrm{Cr}$ III & $\mathrm{Cu}$ & $\mathbf{L i}$ & $\mathbf{M g}$ & $\mathrm{Na}$ & $\mathbf{N i}$ & $\mathrm{Sr}$ & Tl & $\mathbf{Z n}$ \\
\hline $\mathrm{Ca}$ & 1 & & & & & & & & & \\
\hline Cr III & 0.227 & 1 & & & & & & & & \\
\hline $\mathrm{Cu}$ & 0.36 & 0.14 & 1 & & & & & & & \\
\hline $\mathrm{Li}$ & 0.235 & -0.815 & 0.022 & 1 & & & & & & \\
\hline $\mathrm{Mg}$ & -0.26 & 0.564 & -0.047 & -0.785 & 1 & & & & & \\
\hline $\mathrm{Na}$ & -0.363 & 0.085 & -0.334 & -0.352 & 0.805 & 1 & & & & \\
\hline $\mathrm{Ni}$ & -0.002 & 0.602 & -0.018 & -0.632 & 0.758 & 0.668 & 1 & & & \\
\hline $\mathrm{Sr}$ & 0.268 & 0.302 & -0.224 & -0.259 & 0.477 & 0.595 & 0.801 & 1 & & \\
\hline $\mathrm{Tl}$ & -0.226 & 0.515 & -0.085 & -0.759 & 0.974 & 0.833 & 0.758 & 0.538 & 1 & \\
\hline $\mathrm{Zn}$ & 0.123 & 0.164 & 0.946 & -0.139 & 0.044 & -0.267 & 0.049 & -0.267 & 0.022 & 1 \\
\hline
\end{tabular}

\section{Conclusion}

Notably, the physico-chemical parameters in the present study suggest that the groundwaters in the study area are generally good for domestic use per World Health Organization (WHO) standards. Essential and trace metals may occur in environments (water, air and soil) due to natural processes and various anthropogenic activities. Since some of heavy metals have been classified as probable and possible human carcinogens. It is necessary to perform regular monitoring programs of these metals and complemented by human risk assessment if possible.

\section{Appendix}

\begin{tabular}{|c|c|c|c|c|c|c|c|c|c|c|c|c|c|c|c|c|}
\hline Sample sites & As & $\mathrm{Ca}$ & $\mathrm{Cr}$ & $\mathrm{Cu}$ & $\mathrm{Fe}$ & $\mathrm{Li}$ & $\mathrm{Mg}$ & $\mathrm{Na}$ & $\mathrm{Ni}$ & $\mathbf{P b}$ & $\mathrm{Sr}$ & $\mathrm{TI}$ & v & $\mathrm{Zn}$ & $\mathrm{Sr} / \mathrm{Ni}$ Ratio & \begin{tabular}{|l} 
Li/Ni Ratio \\
\end{tabular} \\
\hline 1 & $\mathrm{BDL}$ & 31.56 & 0.0146 & 0.0005 & $\mathrm{BDL}$ & 0.0314 & 5.381 & 67.38 & 0.005 & $\mathrm{BDL}$ & 0.0215 & 0.0591 & 0.0337 & 0.0041 & 4.3 & $\begin{array}{l}6.3 \\
\end{array}$ \\
\hline 2 & 0.0005 & 16.17 & 0.0151 & $\mathrm{BDL}$ & 0.0015 & 0.0123 & 2.873 & 16.1 & 0.0031 & $\mathrm{BDL}$ & 0.0168 & 0.0406 & 0.0424 & 0.0137 & 5.4 & 4.0 \\
\hline 3 & $\mathrm{BDL}$ & 112.9 & 0.0183 & 0.0022 & $\mathrm{BDL}$ & 0.0462 & 1.493 & 4 & 0.0016 & 0.0014 & 0.0088 & 0.0327 & 0.0396 & 0.0059 & 5.5 & 28.9 \\
\hline 4 & $\mathrm{BDL}$ & 49.19 & 0.0157 & 0.001 & BDL & 0.0194 & 5.977 & 72.35 & 0.0042 & BDL & 0.0241 & 0.0727 & 0.0414 & 0.0007 & 5.7 & 4.6 \\
\hline 5 & BDL & 5.787 & $\mathrm{BDL}$ & 0.0019 & BDL & 0.0941 & 0.2914 & 11.04 & $\mathrm{BDL}$ & 0.001 & 0.0153 & 0.0159 & BDL & $\mathrm{BDL}$ & N/A & N/A \\
\hline 6 & $\mathrm{BDL}$ & 106.7 & 0.0154 & 0.0261 & BDL & 0.0436 & 2.908 & 8.341 & 0.0028 & $\mathrm{BDL}$ & 0.0105 & 0.04 & 0.0371 & 0.1743 & 3.8 & 15.6 \\
\hline 7 & $\mathrm{BDL}$ & 19.31 & 0.0188 & 0.0049 & $\mathrm{BDL}$ & 0.0155 & 3.393 & 21.2 & 0.0033 & $\mathrm{BDL}$ & 0.0178 & 0.0475 & 0.0517 & 0.0644 & 5.4 & 4.7 \\
\hline 8 & $\mathrm{BDL}$ & 111 & 0.0228 & 0.0053 & $\mathrm{BDL}$ & 0.0228 & 3.647 & 8.966 & 0.002 & $\mathrm{BDL}$ & 0.0139 & 0.0417 & 0.0565 & 0.01 & 7.0 & 11.4 \\
\hline 9 & $\mathrm{BDL}$ & 138.7 & 0.0215 & 0.0051 & BDL & 0.0492 & 2.271 & 20.44 & 0.0049 & $\mathrm{BDL}$ & 0.0318 & 0.0355 & 0.059 & 0.0086 & 6.5 & 10 \\
\hline 10 & $\mathrm{BDL}$ & 127 & $\mathrm{BDL}$ & 0.003 & $\mathrm{BDL}$ & 0.0916 & 0.4362 & 13.27 & 0.0013 & $\mathrm{BDL}$ & 0.0064 & 0.0249 & $\mathrm{BDL}$ & 0.0031 & 4.9 & 70.5 \\
\hline
\end{tabular}

Figure A1. Detected levels of analyzed parameters in water sources.

\begin{tabular}{|c|c|c|c|c|c|c|c|}
\hline Cd & HPI & HEI & HI & CDI:Cu & CDI:Fe & CDI:Zn & CDI:Pb \\
\hline-3.99868 & -1.04678 & 0.00132 & 0.001193 & $1.57 \mathrm{E}-05$ & 0 & 0.000129 & 0 \\
\hline-3.98976 & -1.04584 & 0.01024 & 0.001435 & 0 & $4.71 \mathrm{E}-05$ & 0.000431 & 0 \\
\hline-3.90329 & -1.04095 & 0.096713 & 0.016548 & $6.91 \mathrm{E}-05$ & 0 & 0.000185 & 0.000044 \\
\hline-3.99886 & -1.04749 & 0.00114 & 0.0016 & $3.14 \mathrm{E}-05$ & 0 & 0.000022 & 0 \\
\hline-3.93143 & -1.04288 & 0.068567 & 0.01188 & $5.97 \mathrm{E}-05$ & 0 & 0 & $3.14 \mathrm{E}-05$ \\
\hline-3.93904 & -1.08331 & 0.06096 & 0.058102 & 0.00082 & 0 & 0.005478 & 0 \\
\hline-3.98222 & -1.05307 & 0.01778 & 0.014227 & 0.000154 & 0 & 0.002024 & 0 \\
\hline-3.9927 & -1.05365 & 0.0073 & 0.009138 & 0.000167 & 0 & 0.000314 & 0 \\
\hline-3.99318 & -1.05336 & 0.00682 & 0.008686 & 0.00016 & 0 & 0.00027 & 0 \\
\hline-3.99638 & -1.05035 & 0.00362 & 0.004904 & $9.43 \mathrm{E}-05$ & 0 & $9.74 \mathrm{E}-05$ & 0 \\
\hline
\end{tabular}

Figure A2. Estimates of Hazards Indices and Chronic daily Intake of $\mathrm{Zn}, \mathrm{Fe}, \mathrm{Cu}$, and $\mathrm{Pb}$.

\section{Acknowledgements}

We highly acknowledge His Majesty Government of Brunei Darussalam for funding this project. State University of Zanzibar (SUZA) for supporting the study. We also thank Hjh Faridah, Hjh Rasiah, Azzlin, Najib and other UBD Chemistry laboratory staffs for their tireless assistance during laboratory analysis.

\section{References}

[1] Adreano AB, Joana S (2007) The quest for safe water: An example from Guinea-Bissau (West Africa). Water Research 41: 2978-2986. 
[2] Affum AO, Osae SD, Nyarko BJB, Afful S, Fianko JR, Akiti TT, et al. (2015)Total coliform, arsenic and Cadmium exposure through drinking water in the Western Region of Ghana. Environmental monitoring and assessment: application of multivariate statistical technique to groundwater quality. Environ Monit Assess 187: 1-23.

[3] Asamoah DN, Amorin R (2011) Assessment of the quality of bottled/sachet water in the Tarkwa-Nsuaem Municipality (TM) of Ghana. Res J Appl Sci Eng Technol 3:377-385.

[4] Ayni FE, Cherif S, Jrad A, Trabelsi-Ayadi M (2011) Impact of treated wastewater reuse on agriculture and aquifer recharge in a coastal area: Korba casestudy. Water Resour Manage 25: $2251-2265$.

[5] Callén E, Di Virgilio M, Kruhlak MJ, Nieto Soler M, Wong N, Chen HT, et al. (2013) 53BP1 mediates productive and mutagenic DNA repair through distinct phosphoprotein interactions. Cell 153: 1266-1280.

[6] Chotpantarat S, Sutthirat C (2011) Different sorption approaches and leachate fluxes affecting on $\mathrm{Mn}^{2+}$ Transport through lateritic aquifer. A J Environ Sci 7: 65-72.

[7] Donahue J. Water (1998) Culture and power: Local struggles in a Global context. Island Press: Washington DC.

[8] Edmund WM, Shand P, Hart P, Ward RS (2003) The natural (baseline) quality of groundwater: a UK pilot study. Sci Total Environ 310: 25-35.

[9] Ghasemi M, Keshtkar AR, Dabbagh R, Jaber Safdari S (2011) Biosorption of uranium in a continuous flow packed bed column using Cystoseira indica biomass. Iran $\mathrm{J}$ Environ Health Sci Eng 8: 65-74.

[10] Hynds PD, Thomas MK, Pintar KDM (2014) Contamination of groundwater systems in the US and Canada by Enteric Pathogens, 1990-2013: a review and pooled-analysis. PLoS One 9(5).

[11] Idris AM, Al-Tayeb MAH, Potgieter-Vermaak Sanja S, Van Greken R, Potgieter JH (2007) Assessment of heavy metals pollution in Sudanese harbours along the Red Sea Coast. Microchem J87: 104-112.

[12] Idris AM (2008) Combining multivariate analysis and geochemical approaches for assessing heavy metal. Microchem J 90: 159-163.

[13] Khodabakhshi A, Amin MM, Mozaffari M (2011) Synthesis of magnetic nanoparticles and evaluation efficiency for arsenic removal from simulated industrial waste water. Iran J Environ Health Sci Eng 8: 189-200.

[14] Marengo E, Gennaro MC, Robotti E, Rossanigo P, Rinaudo C, Roz-Gastaldi M (2006) Investigation of anthropic effects connected with metal ions concentration, organic matter and grain size in Bormida river sediments. Anal Chim Acta 560: $172-183$.
[15] McMurry J, Fay RC (2004) Hydrogen, Oxygen and Water. 4th ed. McMurry Fay Chemistry. K. P. Haman New Jersey: Pearson Education.

[16] Mendie U (2005) In the Theory and Practice of Clean Water Production for Domestic and Industrial Use The Nature of Water. Lagos, Lacto-Medals Publishers.

[17] Mohamed AAJ, Ibrahim AR, Lee HL, Hanna M, Mohamed M, Fadilah T, et al. (2016a)Assessment of Groundwater Quality Parameters in Northern Region of Zanzibar Island. J Chemical Eng Bio Chem 1-8.

[18] Mohamed AAJ, Ibrahim AR, Sadri AS, Lee HL (2014)Occurrence Of Arsenic, Lead, Thallium and Beryllium in Groundwater. A J Envir Scie 164-170.

[19] Mohamed AAJ, Sara AK, Haji M, Miza AK, Said SB (2016b) Risk Assessment on Trace Metals in Groundwater and Springs in Urban Environment of Zanzibar Island. Int J Envir Moni Analy 45-55.

[20] Mohamed AAJ, Ibrahim A, Sadri AS, Lee HL, Islam SM (2013) Levels of Hexavalent Chromium, Copper, and Total Hardness in Springs and Underground Water in Zanzibar Island. Asian J App Scie 212-219.

[21] Öztürk M, Özözen G, Minareci O, Minareci E (2009) Determination of heavy metals in fish, water and sediments of Avsar Dam Lake in Turkey. Iran J Environ Health Sci Eng6: 73-80.

[22] Rashed MN (2010). Monitoring of contaminated toxic and heavy metals from mine tailings through age accumulation in soil and some wild plants at Southeast Egypt. J Hazard Mater 178: 739-746.

[23] Rattan RK, Datta SP, Chhonkar PK, Suribabu K, Singh AK (2005) Long-term impact of irrigation with sewage effluents on heavy metal content in soils, crops and groundwater: a case study. Agric Ecosyst Environ 109: 310-322.

[24] Taboada-Castro M, Diéguez-Villar A, Rodríguez Luz, Blanco M, Teresa Taboada-Castro M (2012) Agricultural impact of dissolved trace elements in runoff water from an experimental catchment with hand-use changes. Commun Soil Sci Plant Anal 43: 81-87.

[25] Underwood EJ (1956) Trace elements in humans and animals nutrition. 3rd ed. Academic Press, New York.

[26] USEPA. Human health risk assessment. 2012; Available: http:// www.epa.gov/risk/health-risk.htm (Accessed 5 April 2016)

[27] Vanloon GW, Duffy SJ (2005) The hydrosphere. In: environmental chemistry: a gold perspective. 2nd ed. Oxford University Press: New York.

[28] WHO (2010) Water for health: WHO Guidelines for Drinkingwater Quality. 